\title{
Analysis of Status of Photovoltaic and Wind Power Abandoned in China
}

\author{
Shimin Li, Jing Wang, Qiong Liu, Lingyan Li, Yaping Hua, Wei Liu \\ Gansu Natural Energy Research Institute, UNIDO International Solar Energy Center for Technology Promotion and Transfer, \\ Key Lab for Gansu Province, Lanzhou, China \\ Email: lishimin@unido-isec.org, wangjing@unido-isec.org, liuqiong@unido-isec.org, lilingyan@unido-isec.org, \\ huayaping@unido-isec.org, liuwei@unido-isec.org
}

How to cite this paper: Li, S.M., Wang, J., Liu, Q., Li, L.Y., Hua, Y.P. and Liu, W. (2017) Analysis of Status of Photovoltaic and Wind Power Abandoned in China. Journal of Power and Energy Engineering, 5, 91-100.

http://dx.doi.org/10.4236/jpee.2017.51007

Received: December 27, 2016

Accepted: January 22, 2017

Published: January 25, 2017

Copyright $\odot 2017$ by authors and Scientific Research Publishing Inc. This work is licensed under the Creative Commons Attribution International License (CC BY 4.0).

http://creativecommons.org/licenses/by/4.0/

\begin{abstract}
It was reported that the total installed capacity of photovoltaic power in China has reached $43.5 \mathrm{GW}$ [1] at the end of 2015. With the vast territory and abundant solar energy resources in western part of China, more than 50 percent of photovoltaic power stations and wind farms were built there. In recent years, influenced by such factors as rapid growth in installed capacity of PV power stations and wind farms, power generation districts far away from power consumption load as well as its mismatch in transmission line, the phenomenon of abandoning solar and wind power has already restricted severely the normal operation of photovoltaic and wind power generation. It has greatly reduced the enthusiasm of the investors and constructors for investing and building power stations. This paper, based on the status in quo of power generation market and power supply in China, analyzes multi-aspect reasons for the phenomenon of abandoning solar and wind power and discusses their solutions.
\end{abstract}

\section{Keywords}

Wind and Solar Power Abandoned, Renewable Energy, Power Consumption

\section{Status of Power Supply in China}

As of 2011, the total installed capacity of photovoltaic power in China only reached 3.5 million $\mathrm{kW}$. However, since China began to implement the National 12th Five-Year Plan for Economic and Social Development of the People's Republic of China (2011-2015), the construction of photovoltaic power station was in "fast traffic lane" and its growth rate has nearly doubled every year. Especially in the first two years in implementing this plan, the growth rate arrived at about 150 percent. In 2015, China's new installed capacity of photovoltaic power reached 
about 15 million $\mathrm{kW}$, with year-on-year growth of 41.5 percent, accounting for 28.3 percent in global new installed capacity. China's new installed capacity ranked the first in three consecutive years around the world [2]. By the end of 2015, the aggregate installed capacity of photovoltaic has amounted to $43.5 \mathrm{GW}$ [3], and the data were presented in Table 1.

Notable progress has been made in curbing environment pollution and reducing greenhouse gas emission since photovoltaic power plants have been built. China's photovoltaic power generation reaches 39.2 billion kWh and it would save or replace 15.68 million tons of standard coal, reduce 39 million tons of carbon dioxide emission and 10.6 tons of carbon dust, if calculated by $0.4 \mathrm{~kg}$ of standard coal consumption, $0.997 \mathrm{~kg}$ of carbon dioxide reduction and $0.272 \mathrm{~kg}$ of carbon dust per kWh according to the benefit of power conservation and emission reduction of coal-power generation [4]. China's photovoltaic generation is expected to reach 200 billion kWh by 2020 and replace 80 million tons of standard coal and reduce 199 million tons of carbon dioxide emission [5], which created enormous economic and environmental benefits.

Over the past decade, owing to the strong demand for electricity with the rapid economic growth in China, the photovoltaic industry gained rapid growth. China's power supply was less than demand and the gap in power supply was relatively large. Especially, the shortage of electricity in many developed cities in eastern China has led to power rationing when power consumption peaked during which power outage in one or two days often occurred. Stimulated by the strong domestic power demand, the installed capacity of solar power, wind power and other renewable energies as well as conventional thermal power has gained rapid growth. However, in recent years, China's power supply exceeds the demand because of the effects of the global financial crisis on China's economy and China's industrial restructuring in economy that is modified from double-digit growth to a "new normal" development rate, which led to phenomenon of abandoning wind and solar power. This phenomenon began in 2011in China and has become much more severe in many regions in recent years, due

Table 1. Statistics of China's installed capacity and power generation in 2015 [9].

\begin{tabular}{|c|c|c|c|c|}
\hline & $\begin{array}{l}\text { Total installed } \\
\text { capacity (GW) }\end{array}$ & $\begin{array}{l}\text { Power generation } \\
\text { (Billion kWh) }\end{array}$ & $\begin{array}{l}\text { Ratio of power } \\
\text { generation (\%) }\end{array}$ & Note \\
\hline Coal power & 990 & 4097.2 & 73 & l \\
\hline Hydropower & 319 & 1114.3 & 20 & $\begin{array}{c}2.3 \% \text { hydropower } 26.2 \\
\text { kWh abandoned }\end{array}$ \\
\hline Nuclear power & 26 & 120 & 2 & I \\
\hline Wind power & 105 & 186.3 & 3.3 & $\begin{array}{c}18 \% \text { wind power } 33.9 \\
\mathrm{kWh} \text { abandoned }\end{array}$ \\
\hline PV power & 43.5 & 39.2 & 0.7 & $\begin{array}{l}16 \% \mathrm{PV} \text { power } 7.3 \\
\mathrm{kWh} \text { abandoned, }\end{array}$ \\
\hline Others & 4.5 & 3 & 0.05 & I \\
\hline In total & 1488 & 5560 & I & I \\
\hline
\end{tabular}


to such factors as the intensified contradictions between the "grabbing mounted surge" growth in constructing photovoltaic stations and installing of transmission line as well as the decline in demand of electricity. The restriction of solar and wind power is being deteriorated in certain areas such as Guazhou County, Gansu Province where the proportion of restriction on power supply has risen to 70 percent, up from 50 percent in 2014, and even to 80 percent [6].

Statistics provided by the National Energy Administration of China in 2015 showed that wind power generation reached 186.3 billion $\mathrm{kWh}$, accounting for 3.3 percent of total power generation and that national average working hours of wind generator reached 1728 hours, 172 hours down as compared to the previous year, and that the maximum duration of wind power was 2658 hours in Fujian Province while minimum duration was 1184 hours in Gansu Province. In 2015 , the situation of abandoning wind power and restricting its utilization was deteriorated and the annual amount of wind power generation abandoned reached 33.9 billion kWh and this data was presented in Figure 3, attaining a year-onyear growth of 21.3 billion $\mathrm{kWh}$, with 15 percent of average rate of wind power abandoned, an increase of 7 percentage points. The rate of wind power abandoned in such provinces as Inner Mongolia Autonomous Region is about 9.1 billion kWh and abandoned 18 percent, Gansu Province 8.2 billion kWh and 39 percent, Xinjiang Uygur Autonomous Region 7.1 billion kWh and 32 percent, Jilin Province 2.7 billion kWh and 32 percent [7].

In recent years, China's clean energy has gained rapid development. The new installed capacity of wind and photovoltaic power both ranked the first in the world. By the end of 2015, China's total installed capacity of coal power, hydro, wind and photovoltaic reached $990 \mathrm{GW}, 319 \mathrm{GW}, 105 \mathrm{GW}$ and $43.5 \mathrm{GW}$ [8] respectively, and the data were presented in Table 1 and Figure 1. In 2015, the power generation in China is up to $5560 \mathrm{kWh}$ and the coal power is still the main power resource which nearly amounts to 74 percent in China's power generation, and the data was presented in Figure 2.

In 2015, the total amount of power generation of hydropower, wind and solar power abandoned reached over 60 billion $\mathrm{kWh}$ of which the accumulative wind power abandoned came to 33.9 billion $\mathrm{kWh}$, just as the data was presented in

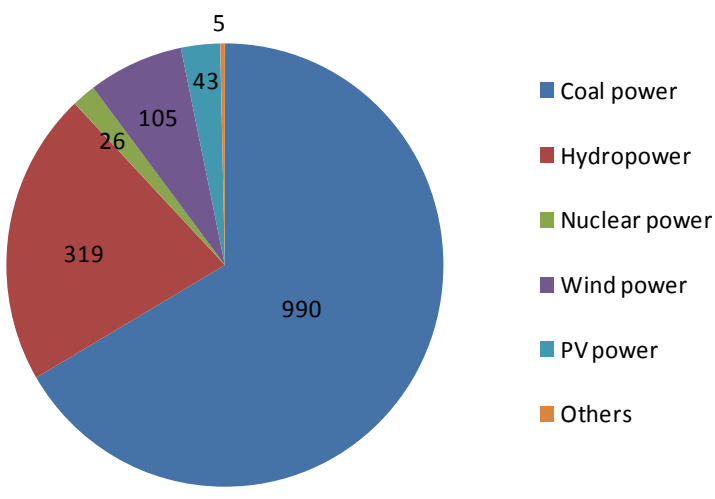

Figure 1. Total installed capacity of electricity generator in $2015(1488 \mathrm{GW})$. 


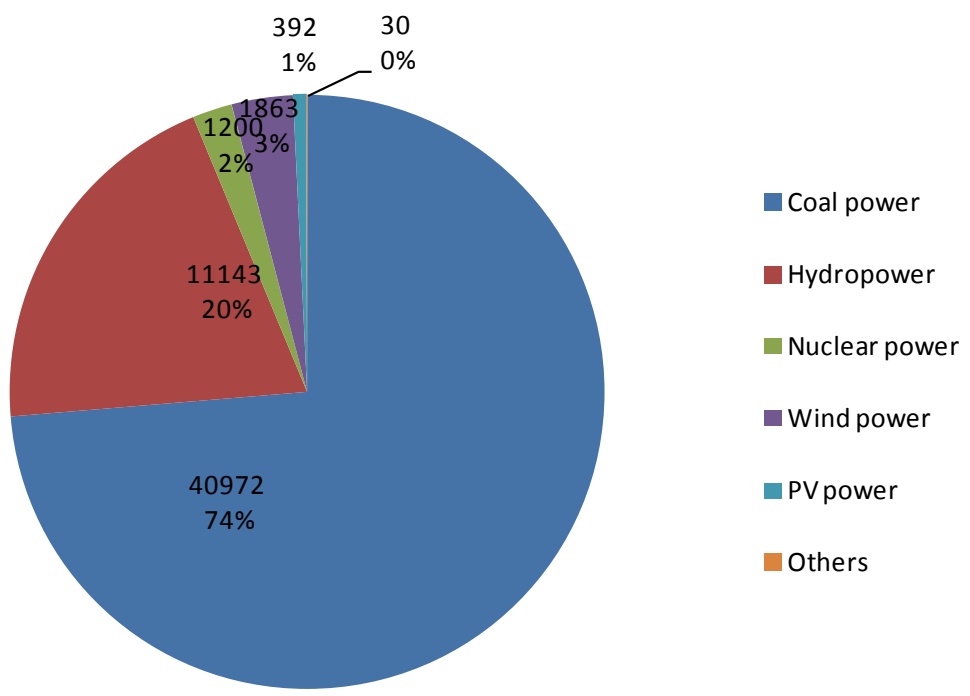

Figure 2. Total power generation in 2015 (5560 billion kWh).

Figure 3. Currently, it is not so common for the phenomenon of abandoning solar energy in China, whereas those regions such as Jiuquan, Gansu Province and Golmud, Qinghai province were subjected to the most severe influence. Even in part regions of China, the proportion of solar power generation abandoned has reached above 20 percent and sometime seven over 60 percent in some districts. In most places, solar power station operates well. Of overview of the whole situation, the average rate of solar power abandoned is about 16 percent in China, but about 31 percent in Gansu Province and 26 percent in Xinjiang Uygur Autonomous Region. The total solar power generation abandoned amounts to 7.3 billion kWh in China, and the data was presented in Figure 4.

After analysis, what causes this problem can be concluded as following aspects.

Firstly, it can boil down to the over-speed development of power industry and overmuch of equipment installed for power generation. Encouraged by highspeed of economic development and the shortage of power supply in last decade, a large quantity of power stations has been built not only in western China where the natural resources are rich, but also in eastern China, a developed area but poor in natural resources compared with the former, where a lot of money has been invested in building newly-increased conventional power plants to mitigate the contradiction between local power supply and west-east power transmission. In addition, the slowdown of recovery of global economy and China's economy entering a "new normal" stage with low developing speed, resulted in slowdown in power demand and oversupply in power market, leading to the overcapacity of installed capacity of power.

Secondly, the construction of grid transmission line cannot meet the needs of development for renewable energies. China being vast territory, lots of renewable energy power stations are constructed in desert areas or Gobi that are far from the cities of which industrial power consumption are large. In those areas, the power cannot be consumed locally and the power transmission capacity 


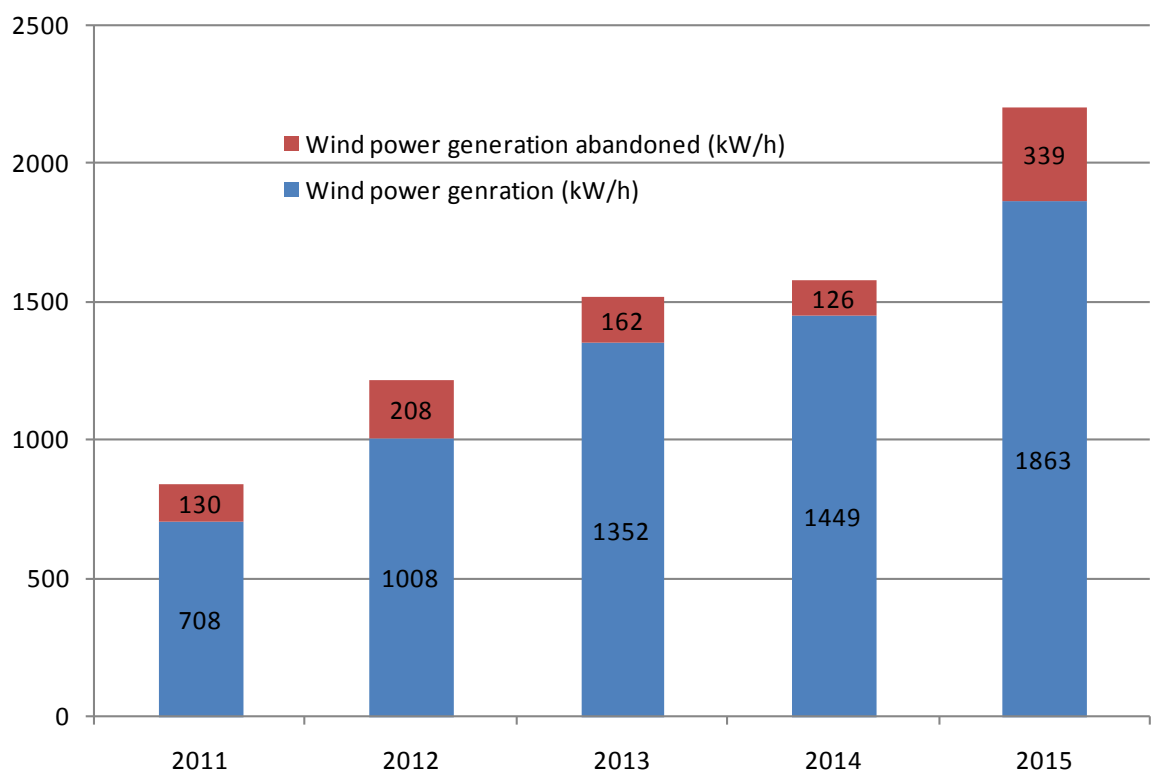

Figure 3. Wind power generation \& abandoned in 2015.

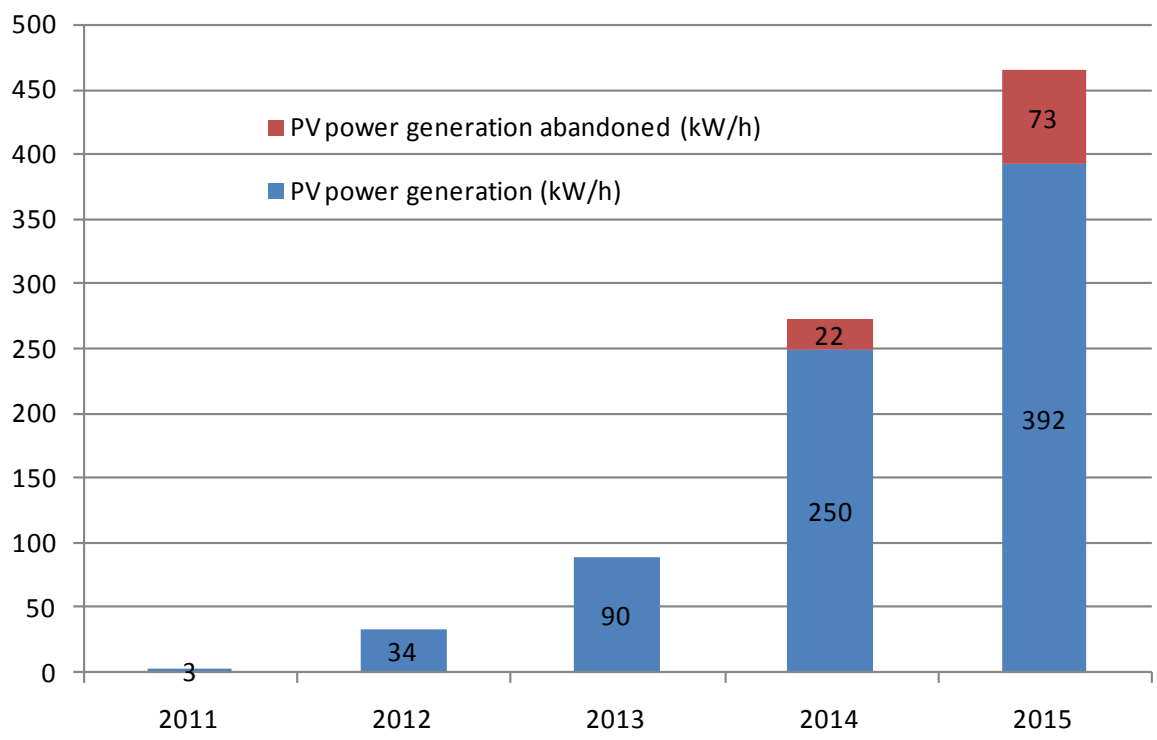

Figure 4. PV power generation \& abandoned in 2015.

cannot be qualified to the need because the speed of construction of long-distance power transmission line cannot keep pace with the construction of power stations, which become the major factors which caused the phenomenon of abandoning solar and wind power in certain regions such as the Hexi Corridor in Gansu Province, Golmud in Qinghai Province and Dabancheng in Xinjiang Uygur Autonomous Region.

Thirdly, owing to solar and wind power's instability, the insufficiency in power peak regulation affects their roles in grid network. Although The Renewable Energy Law in China stipulates that power enterprises should give priority to power dispatching and guarantee purchase in full towards the power generated by renewable energies, still the priority of power dispatching is restricted by the 
mechanism of both the original power operation and price rigidity, making it hard to implement. In China's power structure, coal thermal power is the main form of electricity generation. The depth and speed of pitch peak regulation capability of thermal power are inferior to hydro and gas-fired generator. The current peak regulation capability of China is far below the international level. Massive medium-sized and small coal-fired thermal power generators still adopt old technical and operating mode, without making a upgrading to improve their flexibility according to the new needs. Besides, their technological potentials have not been fully exploited. China's demand side response and swift peak shaving in the power grid are under research and demonstration, whose function isn't fully displayed.

Fourthly, the flexibility of power regulation of power system is weak and the flexibility cannot be fully implemented. Besides, the mechanism and the market for consuming power generated by renewable energy have not been established. The operation and dispatching of power mainly rely on the traditional planned mode so that it cannot adapt to the development of renewable energy. The annual operation hours of power plants in different grade are determined by annual power generation plan. Sometimes, the administrative departments in charge of economy even give quota to each power generating unit. Since the plan of annual thermal power generation is the rigid one, the thermal power enterprise together with the local governments are not willing to make room for other power so that they have to limit the power generation of renewable energy. Such planned mode cannot adapt to the volatility of renewable energy and its needs, so it cannot guarantee their priority access to grid connection. In the future, with the scale of hydropower, wind power and solar power expanding in southwest, northwest, northeast, north area of China, the room of market consumption will gradually become the biggest bottleneck for the development of renewable energy.

\section{Status of China's Renewable Energy Development}

According to the 12th Five-Year Planon energy development, the proportion of non-fossil energy consumption should arrive at 11.4 percent in primary energy consumption, but the desired proportion has not been completed. At the end of 2014, the average annual growth of non-fossil energy consumption was only 0.45 percentage points, up 1.2 percent cumulatively, and only 43 percent of desired target have been fulfilled. To fulfill the proportion of 15 percent of non-fossil energy consumption in primary energy consumption by 2020 , the average annual growth should hit 0.7 percentage points during the period of the 13th FiveYear Plan (2016-2020). Thus, to accelerate the development of hydropower, wind power, solar power has become the main approaches to complete this target. In China's Strategic Planning for Energy Development (2014-2020), it is proposed to vigorously develop renewable energy and the installed capacity of hydropower will have reached about 350 million $\mathrm{kW}$, wind power 200 million $\mathrm{kW}$ and photovoltaic power 100 million $\mathrm{kW}$ by the end of 2020 .

According to data issued by National Energy Administration, in 2014, average 
operation hours of national power plants whose power generation is over 6000 $\mathrm{kW}$ are about 4286 hours, 235 hours down as compared to the previous year in which thermal power operation hour are approximately 4706 hours, 314 hours lower than a year earlier. The data is not only below the highest level of 5991 hours in 2004, but also below the average level of more than 5000 hours for previous three times. Between January and November of 2015, the accumulative average operation hours of national power plants have dropped by 309 hours and of thermal power equipment fell 314 hours from last year's same period. The data which is below 5000 hours of operation hours provided by thermal power generating unit indicates the overcapacity of electricity under the traditional development mode and the decline in power generation and its operating revenues.

It also suggests that the competition in power generation market will be further intensified and the market contradiction among solar, wind, hydropower and thermal power will be deepened.

With the scale of the development and utilization of renewable energy enlarged, renewable energy has changed from a supplement to fossil energy to the alternative. Contradiction between conventional fossil energy and renewable energy in aspects of project layout, market space, and transmission channels is being intensified. The core contradiction of large-scale hydropower, wind power and solar power in power consumption and grid connection has upgraded from peak regulation to the competition in market room and power system restructuring, which should be resolved by national electricity market and "Energy Internet".

In recent years, the restrictions towards solar and wind power in China have become more and more serious. It is a great challenge for China to realize the goal of the proportion of 15 percent of non-fossil energy consumption in primary energy consumption by 2020 . With the current $105 \mathrm{GW}$ wind power installed capacity and $43.5 \mathrm{GW}$ photovoltaic installed capacity whose power generation amounts to $4 \%$ of total power generation, the phenomenon of abandoning solar and wind power is so obvious and it will become more and more severe by 2020 when the solar and wind power generation become double. Therefore, to realize the desired target of renewable energy is a great challenge. What China needs to do is to push forward the dispatching innovation in power operating system in all-round way, to coordinate the construction of associated power network, to release the flexibility of modulating power supply, to promote the power market-oriented reform and to improve the comprehensive management and professional supervision in power system.

The solutions to the problems in detail are as follows.

1) The investment into power grid construction should be strengthened and much attention should be attached into the main grid construction with high voltage power line which should adapt to the needs of large-scale inter-regional renewable energy transmission. In the planning, flexibility study and design of power transmission for twelve lines across East China and West China, the mini- 
mum ratio of renewable energy in the overall power generation should be clearly written. Besides, renewable energy should be prioritized in their practical applications and much attention should be paid to the role of clean energy in optimization in power structure.

2) The principle of the priority of grid-connected consumption of renewable energy should be upheld. Compensation mechanism to assistant market service should be established on the basis of flexible peak regulation capability and technical standards guiding by the scientific, open and transparent principles. The trans-provincial compensation transaction should be expanded and the peak regulation capacity of regular power should be explored through the market. It should gradually open option to power consumption and explore the approaches to directly sale the power generated by renewable energy.

3) For power grid corporations, the profit evaluation index and mechanism should be changed as soon as possible. The evaluation index of renewable energy power consumption in the grid management area and applicable and practical quota system of renewable energy power generation should be introduced. The current management mode in power market which adopts the "beggar-myneighbor" policy and regards the province as the body should be broken so as to explore the new transaction mode of tie-line. Efficient mechanism of interest adjustment should be established by alternative power generation, compensation of cascade hydropower stations and medium-or-long-term strategic cooperation between power feeding and the power receiving part.

4) Grid-connected technology of clean energy and its consumption mechanism should be established which can be used for seizing more market share for power generation by renewable energy. Moreover, the pilot area for priority of dispatching and consuming power generated by renewable energy should be established and the preferential policies should be given in those areas that have difficulty in consuming the clean energy.

5) The transformation and upgrading of energy and electricity grid system shall be further promoted to speed up the development of smart gird, to establish a new type of functional structure in power system that can adapt to support the development of renewable energy. Distributed power generation by renewable energy should be widely applied so as to improve the proportion of solar and wind power generation, which makes it to be the main power resources. However, the proportion of conventional power such as coal-fired or gas-fired power, being the power for peak regulation or even the auxiliary power, should be dropped. The public welfare and service should be emphasized in the power system.

6) A national open and trans-provincial energy internet and power transaction market should be established. The market transaction mechanism should be established, which will regard trans-provincial and inter-regional transaction platforms as breakthrough and takes loosening control for price as precondition. The main bodies of market such as power plants and electricity consumers in those areas above mentioned should directly enter the transaction platform to 
bid freely, which will promote the inter-regional transaction in an orderly way.

7) It is necessary to follow the trend of power market and the requirements of distributed power generation to eliminate the restrictions of market access and to open the market of power-sold side. The monopoly for the purchase and marketing in power market should be changed into freely purchasing and selling, and self-generation and self-consumption mode. The qualified main bodies such as power plants and power consumers should have the privilege of investment, construction and operation into the distribution network. The mechanism suitable to distributed power generation and micro-grid technology should be established.

8) The auxiliary service and capacity price mechanism (referred to market mechanism) should be introduced to facilitate conventional thermal power plants into auxiliary service and capacity provider. With the proportion of new energy power generation increasing, coal-fired power will gradually be used for peak regulation and auxiliary power. Much effort should be made to establish multi part system in electricity tariff, and to create capacity and auxiliary service market mechanism in other forms. When the electricity price is fixed on the basis of bid price and contract price, capacity price and auxiliary service price should be introduced.

9) The mode of gird supervision and performance evaluation should be upgraded. Orientation and obligations of power grid should be reformed to provide service in an open, fair and non-discriminatory way. The only responsibility of power network enterprises is to transmit power instead of buying and selling power. Their due incomes should be separated from revenues and expenditures of generation enterprises and power consumers.

\section{Conclusion}

The problem of abandoning solar and wind power has become an important factor that has severely restricted the normal operation of photovoltaic power and wind power and has reduced the enthusiasm of its investors and constructors. With vast desert areas and rich solar and wind resources, western China has a huge potential to develop solar and wind energy. Undoubtedly, the development of solar and wind energy in eastern China, the west-east electricity transmission project and enhancing the capability of power peak regulation dispatching and transmission should be further strengthened in the future so that the role of renewable energy can be upgraded from the supplementary to the alternative. Much attention should be attached to promoting the development of the local economy and formulating a preferential policy to encourage the consumption of the renewable energy locally.

\section{References}

[1] Zhao, Y., Zhao, Y.W., Lü, F. and Li, B.S. (2016) Report on China's Photovoltaic Development 2016. Chinese Renewable Energy Society \& China Photovoltaic Society, Beijing.

[2] Ran, Y.P. (2016) Installed Capacity of China's Photovoltaic Power Tops First Glo- 
bally Reaching 43.18 Million kW. People’s Daily, 2016-04-04(03).

[3] International Energy Agency, Photovoltaic Power Systems Programme Task 1. 2015-Snapshot of Global PV Markets. IEA PVPS, Paris, 2016-04-06.

[4] GB2589-81. The General Calculating Rule for Comprehensive Energy Consumption of China.

[5] Ran, Y.P. (2016) Ranking First of China's PV Installed Capacity. People’s Daily Overseas Edition, 2016-04-05(01).

[6] Wang, L. and Liang, Q. (2015) The Proportion of PV Power Generation Abandoned Reaching 70 Percent in Many Districts. Economic Information Daily, 2015-0702(02).

[7] China's National Energy Administration (2016) 2015-Monitoring and Evaluation Report on Power Development of Renewable Energy. National Energy Administration, Beijing.

[8] Wang, B. (2016) China's Installed Capacity and Power Generation of Hydropower Top First Globally. Energy Research and Information, No. 1, 10.

[9] Development Department of China Electricity Council (2016) 2016-Analysizing and Predicting Report on Status of Power Supply and Power Demand in China. http://www.chinapower.com.cn/information\&yjbg/20160215/14210.html

Submit or recommend next manuscript to SCIRP and we will provide best service for you:

Accepting pre-submission inquiries through Email, Facebook, LinkedIn, Twitter, etc. A wide selection of journals (inclusive of 9 subjects, more than 200 journals) Providing 24-hour high-quality service User-friendly online submission system Fair and swift peer-review system Efficient typesetting and proofreading procedure Display of the result of downloads and visits, as well as the number of cited articles Maximum dissemination of your research work

Submit your manuscript at: http://papersubmission.scirp.org/

Or contact jpee@scirp.org 